\title{
Thermochemical Parameters of Tetramethylthiourea Adducts of Certain Metal(II) Bromides
}

\author{
Pedro Oliver Dunstan \\ Instituto de Química, Universidade Estadual de Campinas, Campinas, Brazil \\ Email: dunstan@iqm.unicamp.br
}

Received 26 January 2015; accepted 11 February 2015; published 13 February 2015

Copyright (C) 2015 by author and Scientific Research Publishing Inc.

This work is licensed under the Creative Commons Attribution International License (CC BY).

http://creativecommons.org/licenses/by/4.0/

c) (i) Open Access

\begin{abstract}
Complexes of the general formula [ $\mathrm{MBr}_{2}(\mathrm{TMTU})_{\mathrm{n}}$ ] (where $\mathrm{M}$ is $\mathrm{Mn}, \mathrm{Fe}, \mathrm{Co}, \mathrm{Ni}, \mathrm{Cu}, \mathrm{Zn}$ or $\mathrm{Cd}$; TMTU is Tetramethylthiourea; $n$ is $\mathbf{0 . 7 5}, 2$ or 3 ) were obtained by the reaction of salts and ligand in solution. The bromides were selected among several other salts because they had thermochemical data in the literature. Properties as capillary melting points; $\mathrm{C}, \mathrm{H}, \mathrm{N}, \mathrm{Br}$ and metal contents; TG/DTG and DSC curves; and IR and electronic spectra were determined. The values of several thermodynamic parameters for the complexes were found by solution calorimetry. From them, the standard enthalpies of the metal-sulphur coordinated bonds were calculated. The standard enthalpies of the formation of the gaseous phase adducts also were estimated.
\end{abstract}

\section{Keywords}

Enthalpies of Formation, Thermodynamic, Coordinated Bond Enthalpies, Solution Calorimetry, Dissolution Enthalpies, Tetramethylthiourea Adducts

\section{Introduction}

Complexes formed by salts of transition and representative elements with thioamides are mentioned in the literature. M. V. Raja et al. [1] studied thioamide complexes of aryl bromides. R. Sah et al. [2] synthesized and characterized transition Metal(II) complexes of heterocyclic thiomides. H. Ajaz et al. [3] got the crystal structure of complexes of Antimony(II) with thioamides. T. Singh et al. [4] studied thioamide complexes of ruthenium. S. Nadeem et al. [5] studied thioamide complexes of Palladium(II) bromides. I. I. Ozturki et al. [6] characterized thioamide complexes of Antimony(III) bromide. J. Sola et al. [7] studied thioamide complexes of Silver(I) ion. L. S. Sbirna et al. [8] studied several complexes of transition metals with bidentated heterocyclic (N, S) ligands. 
S. K. Misra et al. [9] studied the complexing behavior of thioamide in several transition metal complexes. V. Muresan [10] prepared new thioamide complexes of transition metals. C. Neagoe [11] et al. studied tertiary thioamide complexes of transition metals. F. Zalaru et al. [12] synthesized thioamide complexes of Cu(II). P. O. Dunstan et al. [13] characterized thioamide complexes of arsenic trihalides. H. O. Desseyn [14] studied chelates of thioamides. S. Neagoe et al. [15] studied thioamide complexes of transition metals. C. E. Carraher Jr. et al. [16] studied complexes of polythioamides with Palladium(II). B. Singh [17] studied thioamide complexes of Oxovanadium(IV). G. R. Burns et al. [18] studied thioamide complexes of Chromium(III). J. M. Bret et al. [19] studied thioamide complexes of platinum. V. Muresan et al. [20] prepared several thioamide complexes of transition metals. Yu. N. Kukushkin et al. [21] studied thioamide complexes of Platinum(I). A. J. Aarts et al. [22] studied thioamide complexes of Palladium(II). V. V. Sibirskaya et al. [23] prepared thioamide complexes of platinum metals. M. Molina et al. [24] studied the interaction of thioamides with metals. J. G. H. Du Preez et al. [25] studied thioamide complexes of oxovanadium dichloride.

In this work, complexes formed by tetramethylthiourea with bromides of Manganese(II), Iron(II), Cobalt(II), Nickel(II), Cooper(II), Zinc(II) and Cadmium(II) were studied. Thermodynamic data found in the literature concerning the standard enthalpies of formation of coordinated bonds in this kind of complexes are limited. The knowledge of the thermodynamic properties of these compounds is important to find their applications in catalysis and in the chromatographic separation of metal ions. It could be inferred the affinity order of the metallic ions for stationary-movable chromatographic phases by the knowledge of the formation enthalpies of complexes. Also, the thermochemical parameters can be used in catalysis for finding the more adequate complex to accelerate a given reaction. In this article, calorimetric measurements were made to measure the strength of the metalsulphur coordinated bonds. Correlations of the thermodynamic properties of the complexes were got. The enthalpies of formation of the complexes derived from the gaseous-phase metal ions, bromide ions and tetramethylthiourea were determined.

\section{Materials and Methods}

\subsection{Reagents}

Tetramethylthiourea (RP, Fluka AG Buchs SG) was purified by recrystallization from methanol $\left(\mathrm{MP} 75^{\circ} \mathrm{C}\right.$ $76^{\circ} \mathrm{C}$ ). The anhydrous Metal(II) bromides used in the synthesis of the complexes were of analytical grade. Solvents were distilled and stocking over Linde $4 \AA \AA$ molecular sieves before using.

\subsection{Experimental Procedure}

The complexes were prepared by the reaction between Metal(II) bromides and tetramethylthiourea in a molar ratio salt/ligand of 1/4 in hot tert-buthyl alcohol solution or in a hot mixture ethanol/chloroform solution. Following, an example of one preparation: $1.00 \mathrm{~g}$ of $\mathrm{NiBr}_{2}(4.58 \mathrm{mmol})$ was dissolved in $25 \mathrm{~mL}$ of hot tert-butyl alcohol and $2.41 \mathrm{~g} \mathrm{(18} \mathrm{mmol)} \mathrm{of} \mathrm{tetramethylthiourea} \mathrm{was} \mathrm{dissolved} \mathrm{in} 20 \mathrm{~mL}$ of hot tert-butyl alcohol. The later solution was poured into the solution of the salt, slowly and dropwise with stirring. The mixture was refluxed by five hours after which, the solid that formed was filtered and washed with $60 \mathrm{~mL}$ of petroleum ether divided in three portions. The compound obtained was maintained in a vacuum over twelve hours. It was stocked in desiccator over $\mathrm{CaCl}_{2}$. The chemical analysis confirmed the contains proposed by the assumed stoichiometries. Microanalytical procedures [26] were used for the determination of C, H and N contents. Gravimetric analysis [27] was used to determine the bromine contents. The metal contents were complexometrically determined by using $0.01 \mathrm{M}$ ethylenediaminetetraacetic acid solution [28]. Samples of the compounds in a $\mathrm{KBr}$ matrix were used to get the IR spectra. The region of spectra was from 4000 to $400 \mathrm{~cm}^{-1}$ and a Perkin Elmer 1600 series FTIR spectrophotometer was used. A UV-Vis-NIR spectrophotometer was used to record the spectra of the solid compounds in the region 350 - $2000 \mathrm{~nm}$ using a standard reflectance attachment to get the spectra. TG/DTG and DSC curves were recorded in an argon atmosphere in a Du Pont 951 analyzer. The mass of the compounds was initially between 6.37 and $8.79 \mathrm{mg}$ (TG/DTG) and from 4.80 to $16.14 \mathrm{mg}$ (DSC). A heating rate of $10 \mathrm{~K} \cdot \mathrm{min}^{-1}$ was used from 298 to $678 \mathrm{~K}$ (DSC) and from 298 to $1248 \mathrm{~K}$ (TG/DTG). The calibration for temperatures was conducted with metallic aluminum as a standard (MP = 933.49 K). The equipment performed the calibration for mass automatically. The DSC calibration was made with metallic indium as a standard (MP $=438.85 \mathrm{~K}, \Delta_{\mathrm{s}}^{1} H^{\circ}$ $=28.4 \mathrm{~J} \cdot \mathrm{g}^{-1}$ ). For the calorimetric study of the complexes, an LKB 8700-1 precision calorimeter was used at the 
measurements temperature of $298.15 \pm 0.02 \mathrm{~K}$. A thin-walled ampoule that contained reactant was broken in a glass reaction vessel filled with $(100.00 \mathrm{~mL})$ of calorimetric solvent [29]. The accuracy of the equipment was determined as previously reported [29] [30]. Three to eight replicate measurements were made on each compound and the uncertainty intervals are twice the standard deviations. The experimental deviations of the dissolution measurements stated between (1\% - 3\%).

\section{Results}

\subsection{Complex Characterization}

The interaction of $\mathrm{MBr}_{2}$ with TMTU in solution leads to compounds of definite stoichiometry. Only in the case of $\mathrm{FeBr}_{2}$ the compound formed had a fractional stoichiometry. The yields (Y), capillary melting points (MP), colors, appearance (A) and analytical data are reported in Table 1.

\subsection{Infrared Studies}

Table 2 presents the main IR bands of the complexes. A strong band is observed in the region $1097-1148 \mathrm{~cm}^{-1}$. This band is attributed to the $\mathrm{C}=\mathrm{S}$ stretching frequency $\left(v_{\mathrm{CS}}\right)$ [31]. It is observed in the complexes relative to the free ligand, negative shifts of this frequency and positive shifts of the $v_{\mathrm{CN}}$ frequency after coordination, indicating coordination of the ligand through the sulphur atom to the Metal(II) bromide [31]. Figure 1 presents the IR spectra of the Zn(II) complex.

Table 1. Melting points, yields, appearance and analytical data of the complexes.

\begin{tabular}{|c|c|c|c|c|c|c|c|c|c|c|c|c|c|}
\hline \multirow{2}{*}{ Compound ${ }^{*}$} & \multirow{2}{*}{$\begin{array}{l}\mathrm{Y} \\
\%\end{array}$} & \multirow{2}{*}{$\begin{array}{l}\mathrm{MP}^{\mathrm{a}} \\
{ }^{\circ} \mathrm{C}\end{array}$} & \multirow{2}{*}{$A^{b}$} & \multicolumn{2}{|c|}{$\% \mathrm{C}$} & \multicolumn{2}{|c|}{$\% \mathrm{H}$} & \multicolumn{2}{|c|}{$\% \mathrm{~N}$} & \multicolumn{2}{|c|}{$\% \mathrm{Br}$} & \multicolumn{2}{|c|}{$\% \mathrm{M}$} \\
\hline & & & & Cal. & Obs. & Cal. & Obs. & Cal. & Obs. & Cal. & Obs. & Cal. & Obs. \\
\hline$\left[\mathrm{MnBr}_{2}(\mathrm{~L})_{2}\right]$ & 76 & $150-52$ & y. p. & 25.06 & 25.04 & 5.05 & 4.64 & 11.69 & 11.54 & 33.35 & 33.00 & 11.46 & 11.66 \\
\hline$\left[\mathrm{FeBr}_{2}(\mathrm{~L})_{0.75}\right]$ & 49 & $165-68$ & b. re. pa. & 14.31 & 14.17 & 2.88 & 3.03 & 6.67 & 6.53 & 50.76 & 50.55 & 17.74 & 17.66 \\
\hline$\left[\mathrm{CoBr}_{2}(\mathrm{~L})_{3}\right]$ & 86 & $82-84$ & gr. p. & 29.27 & 29.57 & 5.90 & 5.95 & 13.66 & 13.98 & 25.97 & 25.38 & 9.58 & 9.88 \\
\hline$\left[\mathrm{NiBr}_{2}(\mathrm{~L})_{2}\right]$ & 62 & $160-62$ & g. p. & 24.87 & 24.54 & 5.01 & 4.96 & 11.60 & 11.21 & 33.09 & 33.45 & 12.16 & 12.04 \\
\hline$\left[\mathrm{CuBr}_{2}(\mathrm{~L})_{2}\right]$ & 43 & 80 - 82 & g. p. & 24.62 & 24.87 & 4.96 & 5.35 & 11.49 & 11.85 & 32.76 & 33.01 & 13.03 & 13.25 \\
\hline$\left[\mathrm{ZnBr}_{2}(\mathrm{~L})_{2}\right]$ & 74 & $158-60$ & w. p. & 24.53 & 24.75 & 4.94 & 5.04 & 11.44 & 11.45 & 32.64 & 32.40 & 11.35 & 11.62 \\
\hline$\left[\mathrm{CdBr}_{2}(\mathrm{~L})_{2}\right]$ & 86 & $169-71$ & w. p. & 22.38 & 22.52 & 4.51 & 4.74 & 10.44 & 10.37 & 29.78 & 29.51 & 20.94 & 21.07 \\
\hline
\end{tabular}

${ }^{\mathrm{a}}$ Melting with decomposition. ${ }^{\mathrm{b}}$ Key: y., yellow; b., brown; g., green; w., white; re., redish; gr., greenish; p., powder; pa., paste; ${ }^{*} \mathrm{~L}=\mathrm{TMTU}$.

Table 2. IR absorption bands $\left(\mathrm{cm}^{-1}\right)$ of the compounds.

\begin{tabular}{ccc}
\hline Compound & $\begin{array}{c}\text { Assigment } \\
v_{(\mathrm{CS})}\end{array}$ & $v_{(\mathrm{CN})}$ \\
\hline $\mathrm{TMTU}$ & $1120 \mathrm{~s}$ & $1511 \mathrm{~s}, 1372 \mathrm{~s}$ \\
{$\left[\mathrm{MnBr}_{2}(\mathrm{TMTU})_{2}\right]$} & $1098 \mathrm{~s}$ & $1513 \mathrm{~m}, 1367 \mathrm{~s}$ \\
{$\left[\mathrm{FeBr}_{2}(\mathrm{TMTU})_{0.75}\right]$} & $1067 \mathrm{~s}$ & $1532 \mathrm{w}, 1393 \mathrm{~m}$ \\
{$\left[\mathrm{CoBr}_{2}(\mathrm{TMTU})_{3}\right]$} & $1109 \mathrm{~s}$ & $1558 \mathrm{~s}, 1377 \mathrm{~s}$ \\
{$\left[\mathrm{NiBr}_{2}(\mathrm{TMTU})_{2}\right]$} & $1098 \mathrm{~s}$ & $1512 \mathrm{~m}, 1361 \mathrm{~s}$ \\
{$\left[\mathrm{CuBr}_{2}(\mathrm{TMTU})_{2}\right]$} & $1114 \mathrm{~s}$ & $1537 \mathrm{~s}, 1380 \mathrm{~s}$ \\
{$\left[\mathrm{ZnBr}_{2}(\mathrm{TMTU})_{2}\right]$} & $1110 \mathrm{~s}$ & $1557 \mathrm{~s}, 1382 \mathrm{~s}$ \\
{$\left[\mathrm{CdBr}_{2}(\mathrm{TMTU})_{2}\right]$} & $1108 \mathrm{~s}$ & $1556 \mathrm{~s}, 1390 \mathrm{~s}$ \\
\hline
\end{tabular}

${ }^{a} v$, stretching. Intensity of bands: s, strong; m, medium; w, weak. 


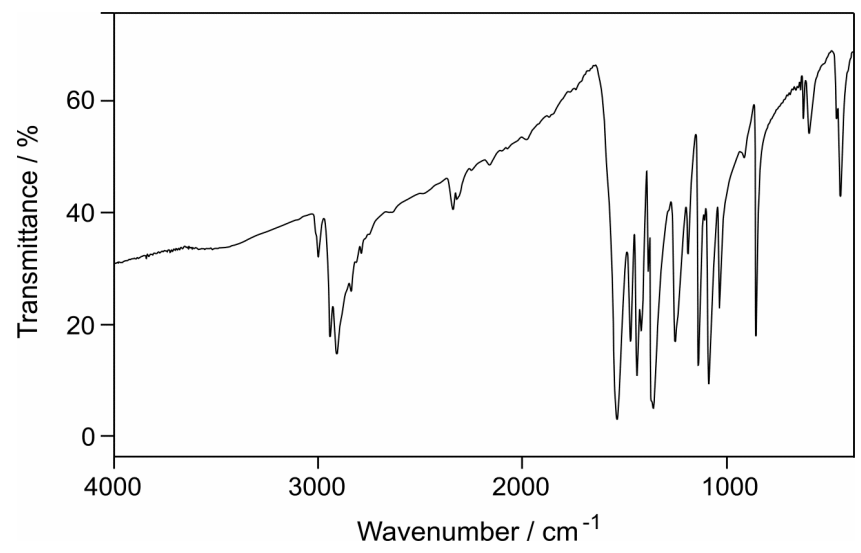

Figure 1. Infrared spectrum of the complex $\left[\mathrm{ZnBr}_{2}(\mathrm{TMTU})_{2}\right]$.

\subsection{Thermal Studies}

The thermogravimetry of the complex of Mn(II) shows the loss of the ligand in three steps of mass loss. In a fourth step it loses part of the bromine content leaving a residue that is part of the bromine content plus the metal content. The complex of Fe(II) shows the loss of the ligand in three steps. Part of the bromine content is lost together with part of the ligand in the third step of mass loss. Part of the bromine content is lost in the fourth and fifth steps of mass loss leaving a residue that is part of the bromine content plus the metal content. The complex of Co(II) shows the loss of ligand in three steps of mass loss. Part of the bromine content is lost together with part of the ligand in the third step. Part of the bromine content is lost in a fourth step of mass loss leaving a residue that is part of the bromine content plus the metal content. The complex of $\mathrm{Ni}$ (II) shows the loss of the ligand in the first step of mass loss follow by the loss of part of the bromine content in a second step of mass loss leaving a residue that is part of the bromine content plus the metal content. The complex of $\mathrm{Cu}(\mathrm{II})$ shows the loss of the ligand in the first step of mass loss together with part of the bromine content. The rest of the bromine content together with part of the metal content is lost in the second step of mass loss leaving a residue that is part of the metal content. The complex of $\mathrm{Zn}(\mathrm{II})$ shows the loss of the ligand in three steps of mass loss. The bromine content is lost together with part of the metal in the third step of mass loss. Part of the metal content is lost in the fourth step of mass loss leaving a residue that is part of the metal content. The complex of Cd(II) shows the loss of the ligand in two steps of mass loss follow by the loss of the bromine content and part of the metal content in the third step of mass loss leaving a residue that is part of the metal content. Figure 2 presents the TG/DTG curve of the Co(II) complex. The DSC curves of the complexes are consistent with the TG data. They present endothermic peaks due to the elimination of part of the ligand or part of the bromine content alone or together with part of the ligand. An exothermic peak is observed in the DSC curve of the Fe(II) complex due to the decomposition of the complex. Figure 3 presents the DSC curve of the Co(II) complex. Table 3 presents the thermoanalytical data for the complexes.

\subsection{Electronic Spectra}

The ligand field parameters for the Ni(II) complex were calculated according to Reedijk et al. [32] and Lever [33]. The number and position of the observed bands and the magnitude of the crystal field parameters as compared with that of Bolster [34] indicates that the $\mathrm{Ni}(\mathrm{II})$ complex is pseudo-tetrahedral with the $\mathrm{Ni}(\mathrm{II})$ ion surrounded by two bromide ions and two sulphur atoms from two ligand molecules. The Co(II) complex shows bands attributed to pseudo-octahedral species with Co(II) ion surrounded by three bromide ions and three sulphur atoms from three ligand molecules in a dimeric structure of bridging bromide ions. The ligand field parameters were calculated according to Lever [33]. The electronic spectra of $\mathrm{Cu}(\mathrm{II})$ complex shows a rather broad and symmetrical band which position according to Bolster [34] corresponds to pseudo-tetrahedral species with the $\mathrm{Cu}(\mathrm{II})$ ion surrounded by two bromide ions and two sulphur atoms from two ligand molecules. The ligand field parameters of the Fe(II) complex were calculated according to Bolster [34]. It is concluded that Fe(II) ion is pseudo-octahedral with units $\left[\mathrm{FeBr}_{6}\right]^{4-}$ and $\left[\mathrm{FeBr}_{5} \mathrm{~L}\right]^{3-}$ in a molar relation of $1: 3$ in a polymeric chain of 
Table 3. Thermal analysis of the compounds.

\begin{tabular}{|c|c|c|c|c|c|c|c|}
\hline \multirow{2}{*}{ Compound* } & \multirow{2}{*}{$\begin{array}{c}\text { Apparent } \\
\text { MP/K }\end{array}$} & \multicolumn{2}{|c|}{ Mass loss/\% } & \multirow{2}{*}{$\begin{array}{l}\text { TG temperature } \\
\text { range } / \mathrm{K}\end{array}$} & \multirow{2}{*}{ Species lost } & \multirow{2}{*}{$\begin{array}{l}\text { DSC peak } \\
\text { temperature }\end{array}$} & \multirow{2}{*}{$\Delta H^{\mathrm{o}} / \mathrm{kJ} \cdot \mathrm{mol}^{-1}$} \\
\hline & & Calcd. & Obs. & & & & \\
\hline \multirow[t]{5}{*}{$\mathrm{MnBr}_{2}\left(\mathrm{~L}_{2}\right]$} & $423-25$ & 1.93 & 1.84 & $325-353$ & $-0.07 \mathrm{~L}$ & 346 & 1.53 \\
\hline & & 38.65 & 38.21 & $353-487$ & $-1.41 \mathrm{~L}$ & 421 & 35.99 \\
\hline & & 14.63 & 16.19 & $487-564$ & $-0.53 \mathrm{~L}$ & & \\
\hline & & 28.34 & 28.39 & $884-962$ & $-1.7 \mathrm{Br}$ & & \\
\hline & & & $15.00^{\mathrm{a}}$ & & & & \\
\hline \multirow[t]{6}{*}[\mathrm{FeBr}_{2}(\mathrm{L})_{0.75}]{} & $438-41$ & 9.00 & 8.67 & $375-494$ & $-0.21 \mathrm{~L}$ & 349 & -5.66 \\
\hline & & 13.50 & 12.72 & $494-531$ & $-0.32 \mathrm{~L}$ & 413 & 2.33 \\
\hline & & 26.26 & 26.08 & $531-700$ & $-0.22 \mathrm{~L}-0.68 \mathrm{Br}$ & 469 & 1.33 \\
\hline & & 19.29 & 19.69 & $700-858$ & $-0.76 \mathrm{Br}$ & 510 & 0.32 \\
\hline & & 4.06 & 4.07 & $858-915$ & $-0.16 \mathrm{Br}$ & & \\
\hline & & & $28.77^{\mathrm{a}}$ & & & & \\
\hline \multirow[t]{5}{*}{$\mathrm{CoBr}_{2}\left(\mathrm{~L}_{3}\right]$} & $355-57$ & 25.79 & 25.53 & $353-389$ & $-1.20 \mathrm{~L}$ & 340 & 30.36 \\
\hline & & 26.86 & 26.61 & $389-538$ & $-1.25 \mathrm{~L}$ & 385 & 9.77 \\
\hline & & 15.71 & 16.03 & $538-564$ & $-0.55 \mathrm{~L}-0.3 \mathrm{Br}$ & & \\
\hline & & 18.17 & 18.67 & $564-861$ & $-1.4 \mathrm{Br}$ & & \\
\hline & & & $13.16^{\mathrm{a}}$ & & & & \\
\hline \multirow[t]{3}{*}{$\mathrm{NiBr}_{2}\left(\mathrm{~L}_{2}\right]$} & $433-35$ & 54.76 & 55.24 & $428-505$ & $-2 \mathrm{~L}$ & 393 & 1.09 \\
\hline & & 28.12 & 27.44 & $505-890$ & $-1.7 \mathrm{Br}$ & 427 & 27.48 \\
\hline & & & $17.32^{\mathrm{a}}$ & & & 442 & 21.49 \\
\hline \multirow[t]{3}{*}[\mathrm{CuBr}_{2}(\mathrm{L})_{2}]{} & $353-55$ & 70.60 & 68.07 & $398-484$ & $-2 \mathrm{~L}-\mathrm{Br}$ & 352 & 38.19 \\
\hline & & 26.80 & 26.76 & $484-838$ & $-\mathrm{Br}-0.8 \mathrm{Cu}$ & 441 & 2.62 \\
\hline & & & $5.17^{\mathrm{a}}$ & & & & \\
\hline \multirow[t]{5}{*}[\mathrm{ZnBr}_{2}(\mathrm{L})_{2}]{} & $433-35$ & 35.10 & 35.09 & $434-591$ & $-1.3 \mathrm{~L}$ & 430 & 38.51 \\
\hline & & 13.54 & 13.24 & $591-615$ & $-0.5 \mathrm{~L}$ & & \\
\hline & & 46.05 & 46.26 & $615-760$ & $-0.2 \mathrm{~L}-2 \mathrm{Br}-0.6 \mathrm{Zn}$ & & \\
\hline & & 1.34 & 0.83 & $760-942$ & $-0.1 \mathrm{Zn}$ & & \\
\hline & & & $4.58^{\mathrm{a}}$ & & & & \\
\hline \multirow[t]{4}{*}[\mathrm{CdBr}_{2}(\mathrm{L})_{2}]{} & $442-44$ & 36.96 & 36.62 & $412-570$ & $-1.5 \mathrm{~L}$ & 434 & 42.08 \\
\hline & & 12.32 & 13.15 & $570-580$ & $-0.5 \mathrm{~L}$ & & \\
\hline & & 49.67 & 49.12 & $784-838$ & $-2 \mathrm{Br}-0.95 \mathrm{Cd}$ & & \\
\hline & & & $1.11^{\mathrm{a}}$ & & & & \\
\hline
\end{tabular}

${ }^{\mathrm{a}}$ Residue at $1243 \mathrm{~K} ;{ }^{*} \mathrm{~L}=\mathrm{TMTU}$. 


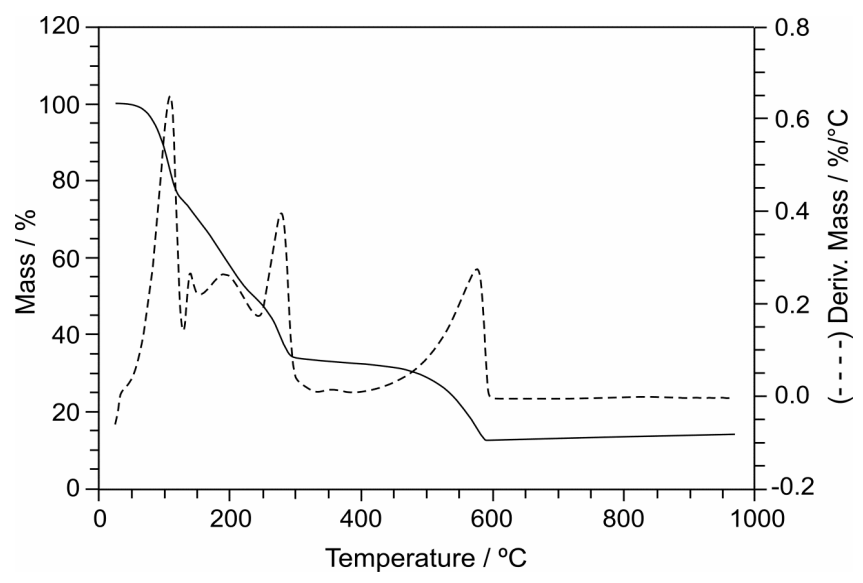

Figure 2. TG/DTG curve of the complex $\left[\mathrm{CoBr}_{2}(\mathrm{TMTU})_{3}\right]$.

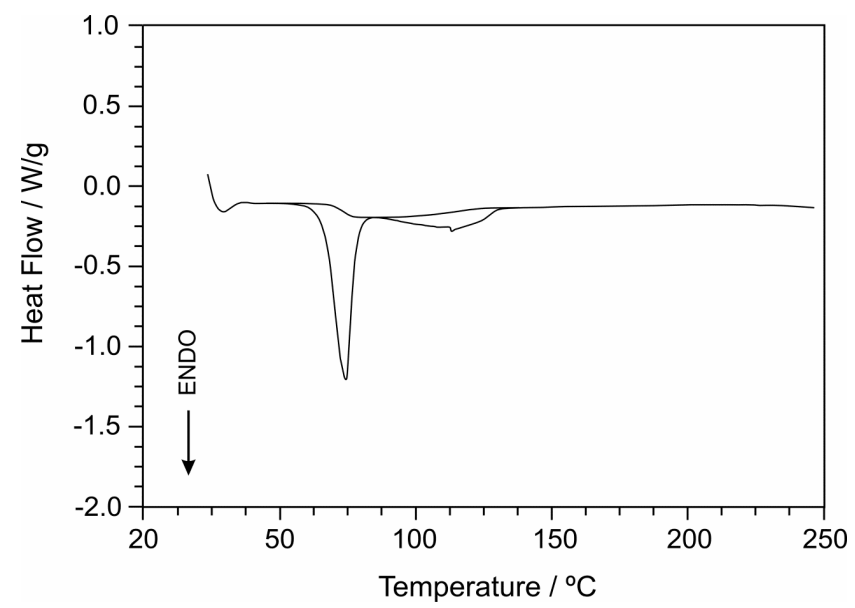

Figure 3. DSC curve of the complex $\left[\mathrm{CoBr}_{2}(\mathrm{TMTU})_{3}\right]$.

bridging bromide ions. The complex of Mn(II) according with the position of the absorption band [34] is pseudo-tetrahedral with the manganese ion surrounded by two bromide ions and two sulphur atoms from two ligand molecules. Table 4 contains the band maxima assignments and calculated ligand field parameters of the complexes.

\subsection{Calorimetric Measurements}

The standard enthalpies of dissolution of Metal(II) bromides, TMTU and complexes were measured [35]. The standard enthalpies of the following reactions were obtained:

$$
\begin{array}{cr}
\mathrm{MBr}_{2(\mathrm{~s})}+\text { calorimetric solvent } \rightarrow \text { solution A ; } & \Delta_{1} H^{\mathrm{o}}(1) \\
\mathrm{nTMTU}_{(\mathrm{s})}+\text { solution A } \rightarrow \text { solution B ; } & \Delta_{2} H^{\mathrm{o}}(2) \\
{\left[\mathrm{MBr}_{2}(\mathrm{TMTU})_{\mathrm{n}}\right]_{(\mathrm{s})}+\text { calorimetric solvent } \rightarrow \text { solution C ; }} & \Delta_{3} H^{\mathrm{o}}(3) \\
\text { Solution B } \rightarrow \text { solution C. } & \Delta_{4} H^{\mathrm{o}}(4)
\end{array}
$$

The application of the Hess' law to the reactions 1 to 4 gives the standard enthalpies of reaction $\left(\Delta_{\mathrm{r}} H^{0}\right)$ :

$$
\mathrm{MBr}_{2}+\mathrm{nTMTU}_{(\mathrm{s})} \rightarrow\left[\mathrm{MBr}_{2}(\mathrm{TMTU})_{\mathrm{n}}\right]_{(\mathrm{s})} ;
$$

being $\Delta_{\mathrm{r}} H^{\mathrm{o}}=\Delta_{1} H^{\mathrm{o}}+\Delta_{2} H^{0}-\Delta_{3} H^{\circ}$, because $\Delta_{4} H^{\mathrm{o}}=0$ for the dissolution of solution B into solution C. Table 5 
Table 4. Band maxima and calculated ligand field parameters for the complexes.

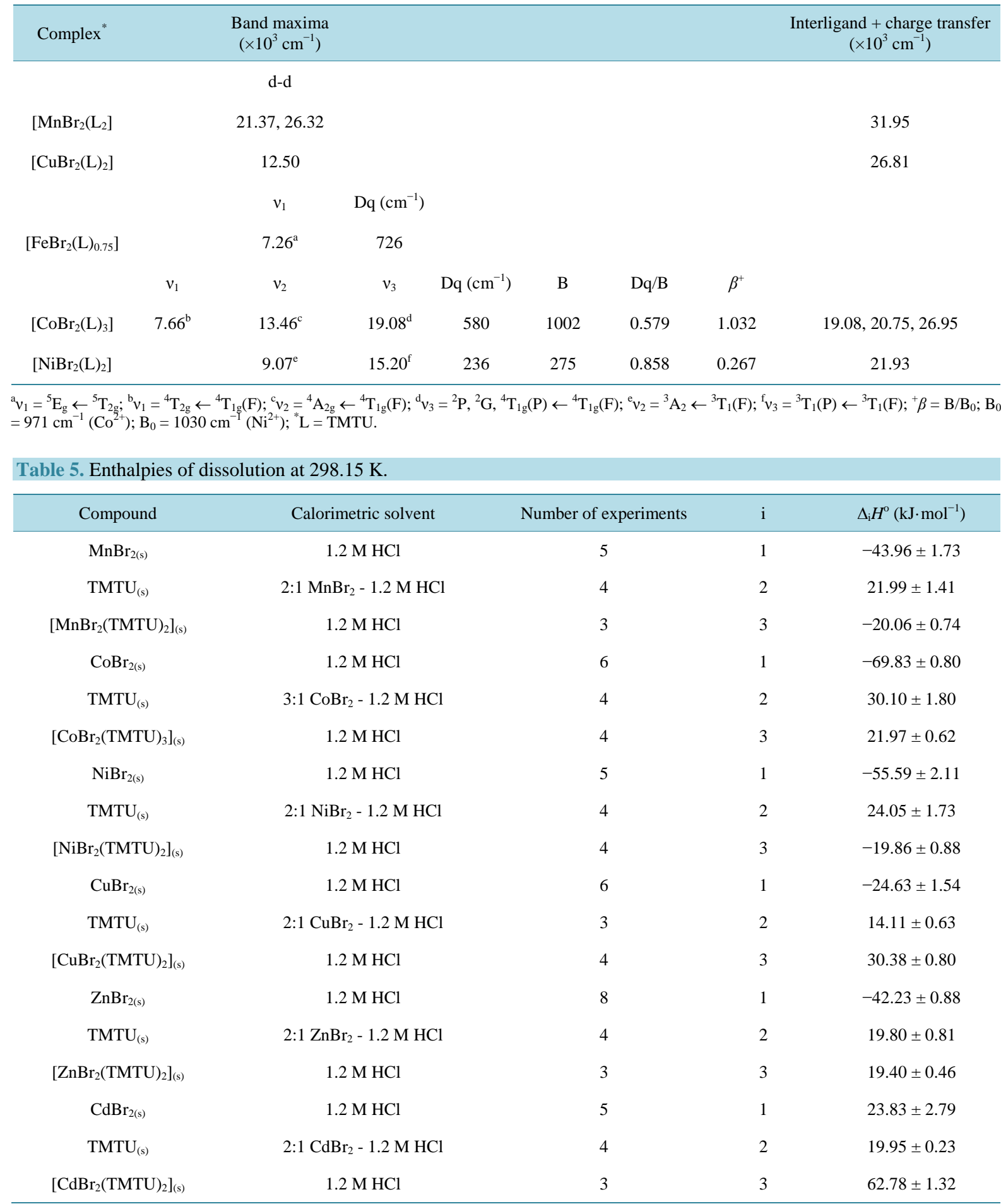

presents the values observed for the enthalpies of dissolution of $\operatorname{MBr}_{2}\left(\Delta_{1} H^{0}\right)$, for the enthalpies of dissolution of TMTU into the solution of $\operatorname{MBr}_{2}\left(\Delta_{2} H^{0}\right)$ and that of the complexes $\left(\Delta_{3} H^{0}\right)$. It was not possible to measure the enthalpies of dissolution of the complex of $\mathrm{Fe}(\mathrm{II})$ due to its paste consistency that made it difficult its manipulation. Uncertainty intervals given in this table are twice the standard deviations of the mean of 3 to 8 replicate measurements. 


\section{Discussions}

Using the standard enthalpies of reaction $\left(\Delta_{\mathrm{r}} H^{0}\right)$ and appropriate thermochemical cycles [35], the following thermochemical parameters were got: the standard enthalpies of formation $\left(\Delta_{\mathrm{f}} H^{0}\right)$ from Equation (5),

$$
\Delta_{\mathrm{f}} H^{\mathrm{o}}(\text { complex })=\Delta_{\mathrm{r}} H^{\mathrm{o}}+\Delta_{\mathrm{r}} H^{\mathrm{o}}\left(\mathrm{MBr}_{2(\mathrm{~s})}\right)+\mathrm{n} \Delta_{\mathrm{f}} H^{\mathrm{o}}\left(\mathrm{TMTU}_{(\mathrm{s})}\right)
$$

the standard enthalpies of decomposition $\left(\Delta_{\mathrm{D}} H^{0}\right)$ from Equation (6),

$$
\left[\mathrm{MBr}_{2}(\mathrm{TMTU})_{\mathrm{n}}\right]_{(\mathrm{s})} \rightarrow \mathrm{MBr}_{2(\mathrm{~s})}+\mathrm{nTMTU}_{(\mathrm{g})} ;
$$

being $\Delta_{\mathrm{D}} H^{\mathrm{o}}=\Delta_{\mathrm{r}} H^{\circ}+\mathrm{n} \Delta_{\mathrm{s}}^{\mathrm{g}} H^{\mathrm{o}}\left(\mathrm{TMTU}_{(\mathrm{s})}\right)$. The standard lattice enthalpy $\left(\Delta_{\mathrm{M}} H^{\mathrm{o}}\right)$, from Equation (7),

$$
\mathrm{MBr}_{2(\mathrm{~g})}+\mathrm{nTMTU}_{(\mathrm{g})} \rightarrow\left[\mathrm{MBr}_{2}(\mathrm{TMTU})_{\mathrm{n}}\right]_{(\mathrm{s})} ;
$$

being $\Delta_{\mathrm{M}} H^{\circ}=-\Delta_{\mathrm{D}} H^{\mathrm{o}}-\Delta_{\mathrm{s}}^{\mathrm{g}} H^{\mathrm{o}}\left(\mathrm{MBr}_{2(\mathrm{~s})}\right)$. The enthalpy of reaction in the gaseous phase, from Equation (8)

$$
\mathrm{MBr}_{2(\mathrm{~g})}+\mathrm{nTMTU}_{(\mathrm{g})} \rightarrow\left[\mathrm{MBr}_{2}(\mathrm{TMTU})_{\mathrm{n}}\right]_{(\mathrm{s})} ;
$$

being $\Delta_{\mathrm{r}} H^{\mathrm{o}}(\mathrm{g})=-\Delta_{\mathrm{s}}^{\mathrm{g}} H^{\mathrm{o}}\left(\mathrm{MBr}_{2(\mathrm{~s})}\right)-\mathrm{n} \Delta_{\mathrm{s}}^{\mathrm{g}} H^{\mathrm{o}}\left(\mathrm{TMTU}_{(\mathrm{s})}\right)+\Delta_{\mathrm{r}} H^{\mathrm{o}}+\Delta_{\mathrm{s}}^{\mathrm{g}} H^{\mathrm{o}}\left(\operatorname{complex}_{(\mathrm{s})}\right)$.

As the complexes decomposed on heating, the enthalpies of sublimation of the complexes were estimated [36].

From Equation (8) it is got the standard enthalpies of the metal-sulphur bonds: $D_{(\mathrm{M}-\mathrm{S})}=-\left(\Delta_{\mathrm{r}} H^{\circ}(\mathrm{g})\right) / \mathrm{n}$. Table 6 presents the values obtained for all these enthalpies. The formation enthalpies of the complexes in the gaseous phase, according to the Equation (9)

$$
\mathrm{M}_{(\mathrm{g})}^{2+}+2 \mathrm{Br}_{(\mathrm{g})}^{-}+\mathrm{nTMTU}_{(\mathrm{g})} \rightarrow\left[\mathrm{MBr}_{2}\left(\mathrm{TMTU}_{\mathrm{n}}\right]_{(\mathrm{g})} ;\right.
$$

are equal to $\Delta_{\mathrm{fl}} H^{\mathrm{o}}=\Delta_{\mathrm{f}} H^{\mathrm{o}}($ complex $)-\Delta_{\mathrm{f}} H^{\mathrm{o}}\left(\mathrm{M}_{(\mathrm{g})}^{2+}\right)-2 \Delta_{\mathrm{f}} H^{\mathrm{o}}\left(\mathrm{Br}_{(\mathrm{g})}^{-}\right)-\mathrm{n} \Delta_{\mathrm{f}} H^{\mathrm{o}}\left(\mathrm{TMTU}_{(\mathrm{g})}\right)$. Table 7 shows the values obtained for these enthalpies values.

\begin{tabular}{|c|c|c|c|c|c|c|c|}
\hline Compound & $\Delta_{\mathrm{r}} H^{\mathrm{o}}$ & $\Delta_{\mathrm{f}} H^{\mathrm{o}}$ & $\Delta_{\mathrm{s}}^{\mathrm{g}} H^{\circ}$ & $\Delta_{\mathrm{M}} H^{\circ}$ & $\Delta_{\mathrm{D}} H^{\circ}$ & $\Delta_{\mathrm{r}} H^{\mathrm{o}}(\mathrm{g})$ & $D_{(\mathrm{M}-\mathrm{S})}$ \\
\hline $\mathrm{MnBr}_{2(\mathrm{~s})}$ & & $-384.9^{\mathrm{a}}$ & $205.9^{\mathrm{a}}$ & & & & \\
\hline $\mathrm{CoBr}_{2(\mathrm{~s})}$ & & $-220.9^{\mathrm{a}}$ & $183^{\mathrm{a}}$ & & & & \\
\hline $\mathrm{NiBr}_{2(\mathrm{~s})}$ & & $-212.1^{\mathrm{a}}$ & $170^{\mathrm{a}}$ & & & & \\
\hline $\mathrm{CuBr}_{2(\mathrm{~s})}$ & & $-141.8^{\mathrm{a}}$ & $182.4^{\mathrm{a}}$ & & & & \\
\hline $\mathrm{ZnBr}_{2(\mathrm{~s})}$ & & $-328.65^{\mathrm{a}}$ & $159.7^{\mathrm{a}}$ & & & & \\
\hline $\mathrm{CdBr}_{2(\mathrm{~s})}$ & & $-316.2^{\mathrm{b}}$ & $151.2^{c}$ & & & & \\
\hline $\mathrm{TMTU}_{(\mathrm{s})}$ & & $-38.3 \pm 2.3^{\mathrm{d}}$ & $82.36 \pm 0.20^{\mathrm{d}}$ & & & & \\
\hline$\left[\mathrm{MnBr}_{2}(\mathrm{TMTU})_{2}\right]_{(\mathrm{s})}$ & $-1.91 \pm 2.35$ & $-463.4 \pm 5.5$ & $-228.4 \pm 17.6$ & $-372.5 \pm 3.1$ & $166.63 \pm 2.38$ & $-228.4 \pm 17.6$ & $114.2 \pm 8.8$ \\
\hline$\left[\mathrm{CoBr}_{2}(\mathrm{TMTU})_{3}\right]_{(\mathrm{s})}$ & $-61.70 \pm 2.07$ & $-396.6 \pm 7.5$ & $133 \pm 16$ & $-492 \pm 2$ & $308.78 \pm 2.16$ & $-359 \pm 16$ & $120 \pm 5$ \\
\hline$\left[\mathrm{NiBr}_{2}(\mathrm{TMTU})_{2}\right]_{(\mathrm{s})}$ & $-11.68 \pm 2.87$ & $-300.4 \pm 5.6$ & $126.2 \pm 15.1$ & $-346.5 \pm 3.1$ & $176.40 \pm 2.90$ & $-220.3 \pm 15.4$ & $110.2 \pm 7.7$ \\
\hline$\left[\mathrm{CuBr}_{2}(\mathrm{TMTU})_{2}\right]_{(\mathrm{s})}$ & $-40.90 \pm 1.85$ & $-259.3 \pm 3.6$ & $132.4 \pm 15.9$ & $-388 \pm 2$ & $205.62 \pm 1.89$ & $-256 \pm 16$ & $128 \pm 8$ \\
\hline$\left[\mathrm{ZnBr}_{2}(\mathrm{TMTU})_{2}\right]_{(\mathrm{s})}$ & $-41.83 \pm 1.28$ & $-447.1 \pm 5.2$ & $121.0 \pm 14.5$ & $-366.3 \pm 2.4$ & $206.55 \pm 1.34$ & $-245.3 \pm 14.7$ & $122.7 \pm 7.4$ \\
\hline$\left[\mathrm{CdBr}_{2}(\mathrm{TMTU})_{2}\right]_{(\mathrm{s})}$ & $-19.00 \pm 3.10$ & $-131.8 \pm 5.6$ & $116.8 \pm 14.0$ & $-334.9 \pm 3.3$ & $187.72 \pm 3.13$ & $-218.1 \pm 14.4$ & $109.1 \pm 7.2$ \\
\hline
\end{tabular}

The acidity order obtained based on $\Delta_{\mathrm{r}} H^{0}$ values for the complexes of the same stoichiometry is: $\mathrm{Zn}(\mathrm{II})>$ $\mathrm{Cu}(\mathrm{II})>\mathrm{Cd}(\mathrm{II})>\mathrm{Ni}(\mathrm{II})>\mathrm{Mn}(\mathrm{II})$. Using the $D_{(\mathrm{M}-\mathrm{S})}$ values the, order is: $\mathrm{Cu}(\mathrm{II})>\mathrm{Zn}(\mathrm{II})>\mathrm{Mn}(\mathrm{II})>\mathrm{Ni}(\mathrm{II})>$ Cd(II).

Table 6. Summary of the thermochemical results $\left(\mathrm{kJ} \cdot \mathrm{mol}^{-1}\right)$ for the compounds.

$\mathrm{a}[37] ;{ }^{\mathrm{b}}[38] ;{ }^{\mathrm{c}}[39] ; \mathrm{d}[40]$. 
Table 7. Auxiliary data and enthalpy changes of the complex formation process in the gaseous phase $\left(\mathrm{kJ} \cdot \mathrm{mol}^{-1}\right)$.

\begin{tabular}{|c|c|c|c|}
\hline Compound & $\Delta_{\mathrm{f}} H^{\mathrm{o}}$ & $\Delta_{\mathrm{r}} H^{\mathrm{o}}(\mathrm{g})$ & $\Delta_{\mathrm{fl}} H^{\mathrm{o}}$ \\
\hline $\mathrm{Br}_{(\mathrm{g})}^{-}$ & $-219.07^{\mathrm{a}}$ & & \\
\hline $\mathrm{Mn}_{(\mathrm{g})}^{2+}$ & $2522.0 \pm 0.1^{\mathrm{b}}$ & & \\
\hline $\mathrm{Co}_{(\mathrm{g})}^{2+}$ & $2841.7 \pm 3.4^{\mathrm{b}}$ & & \\
\hline $\mathrm{Ni}_{(\mathrm{g})}^{2+}$ & $2930.5 \pm 1.5^{\mathrm{b}}$ & & \\
\hline $\mathrm{Cu}_{(\mathrm{g})}^{2+}$ & $3054.5 \pm 2.1^{\mathrm{b}}$ & & \\
\hline $\mathrm{Zn}_{(\mathrm{g})}^{2+}$ & $2781.0 \pm 0.4^{\mathrm{b}}$ & & \\
\hline $\mathrm{Cd}_{(\mathrm{g})}^{2+}$ & $2623.54^{\mathrm{a}}$ & & \\
\hline$\left[\mathrm{MnBr}_{2}(\mathrm{TMTU})_{2}\right]_{(\mathrm{g})}$ & $-319.2 \pm 18.2$ & $-228.4 \pm 17.6$ & $-2491.3 \pm 18.3$ \\
\hline$\left[\mathrm{CoBr}_{2}(\mathrm{TMTU})_{3}\right]_{(\mathrm{g})}$ & $-265 \pm 17$ & $-359 \pm 16$ & $-2801 \pm 19$ \\
\hline$\left[\mathrm{NiBr}_{2}(\mathrm{TMTU})_{2}\right]_{(\mathrm{g})}$ & $-174 \pm 16$ & $-220.3 \pm 15.4$ & $-2755 \pm 17$ \\
\hline$\left[\mathrm{CuBr}_{2}(\mathrm{TMTU})_{2}\right]_{(\mathrm{g})}$ & $-127 \pm 17$ & $-256 \pm 16$ & $-2832 \pm 18$ \\
\hline$\left[\mathrm{ZnBr}_{2}(\mathrm{TMTU})_{2}\right]_{(\mathrm{g})}$ & $-326.1 \pm 15.4$ & $-245.3 \pm 14.7$ & $-2757.2 \pm 16.1$ \\
\hline$\left[\mathrm{CdBr}_{2}(\mathrm{TMTU})_{2}\right]_{(\mathrm{g})}$ & $-295 \pm 15$ & $-218.1 \pm 14.4$ & $-3445 \pm 16$ \\
\hline
\end{tabular}

\section{Conclusion}

Solid state complexes were obtained from the interaction in hot tert-buthyl alcohol solution of tetramethylurea with certain divalent transition metal bromides. The complexes decomposed on heating. The dissolution enthalpies were determined for complexes, salts and ligand. By using thermochemical cycles, the energies of the Metal(II)-sulphur coordinated bonds as well as the values of other thermochemical parameters were estimated. The energies of the coordinated bonds have values between 109 and $128 \mathrm{~kJ} \cdot \mathrm{mol}^{-1}$.

\section{References}

[1] Raja, M.U., Ramesh, R. and Liu, Y. (2011) New Binuclear Pd(II) Thioamide Complexes for the Heck Reaction of Aryl Bromides. Tetrahedron Letters, 52, 5427-5430. http://dx.doi.org/10.1016/j.tetlet.2011.07.080

[2] Sah, R., Kumari, S. and Kumar, A. (2011) Synthesis and Characterization of Transition Metal(II) Complexes with HeterocyclicThioamides. Journal of Chemistry, 23, 3563-3565.

[3] Ajaz, H., Hussain, S., Altaf, M., Stoeckli-Evans, H., Isab, A.A., Mahmood, R., Altaf, S. and Ahmad, S. (2011) Synthesis and Characterization of Antimony(III) Complexes of Thioamides, and Crystal Structure of Sb(Imt $\left.\left.)_{2} \mathrm{Cl}_{2}\right]_{2}\left(\mu_{2}-\operatorname{Imt}\right)\right\} \mathrm{Cl}_{2}$ (Imt = Imidazolidine-2-Thione). Chinese Journal of Chemistry, 29, 254-258. http://dx.doi.org/10.1002/cjoc.201190074

[4] Singh, T. and Singh, K.K. (2010) Synthesis and Characterization of New Ruthenium-Aromatic Thioamidenitrosyls. Oriental Journal of Chemistry, 26, 1171-1174.

[5] Nadeem, S., Rauf, M.K., Bolte, M., Ahmad, S., Tirmizi, S.A., Asna, M. and Hameed, A. (2010) Synthesis, Characterization and Antibacterial Activity of Palladium(II) Bromide Complexes of Thioamides; X-Ray Structure of [Pdf(Tetrametylthiourea) $\left.{ }_{4}\right] \mathrm{Br}_{2}$. Transition Metal Chemistry, 35, 555-561. http://dx.doi.org/10.1007/s11243-010-9363-0

[6] Ozturki, I.I., Hadjikakou, S.K., Hadjiliardis, N., Kourkoumelis, N., Kubicki, M., Tasiopoulos, A.J., Scleiman, H., Barsan, M.M., Butler, I.S. and Balzarini, J. (2009) New Antimony(III) Bromide Complexes with Thioamides: Synthesis, Characterization and Cytotatic Properties. Inorganic Chemistry, 48, 2233-2245. http://dx.doi.org/10.1021/ic8019205

[7] Sola, J., Lopez, A., Coxall, R.A. and Clegy, W. (2004) Hidrogen-Bonding Network and Layerd Supra-Molecular Structures Assembled from $\mathrm{ClO}_{4}^{-}$Counterions with Unprecedented Monomeric $\left[\mathrm{AgL}_{2}\right]^{+}$and Chain Polymeric $\left[\mathrm{AgL}_{2}\right]^{\mathrm{nm}+}$ Complex Cations (L = Thioamide or Thiourea-Like Ligands). Journal of Inorganic Chemistry, 24, 48714881. 
[8] Sbirna, L.S., Muresan, V., Sbirna, S., Muresan, N. and Lepadatu, C.I. (2004) Complex Compounds of Ions with d6-10 Configuration with Bidentate Heterocyclic Ligands (N, S). Journal of the Indian Chemical Society, 81, 150-152.

[9] Misra, S.K. and Tewari, U.C. (2002) Complexing Behaviour of Aromatic Thioamides (ArCSNHCOR). Transition Metal Complexes of N-Carboethoxy-4-Chlorobenzene and N-Carboethoxy-4-Bromobenzene Thioamide Ligand. Transition Metal Chemistry, 27, 120-125. http://dx.doi.org/10.1023/A:1013473621826

[10] Muresan, V., Sbirna, L.S., Sbirna, S., Lepadatu, C.I. and Muresan, N. (2001) Transition Metal Complexes with a New Thioamide of the Dibenzofuran Series. Acta Chimica Slovenica, 48, 439-443.

[11] Neagoe, C., Neagoe, S., Neagoe, O., Cercasov, C. and Lepadatu, C. (1999) Complex Compounds of Pd(II), Pt(II), Cu(I) and $\mathrm{Hg}(\mathrm{II})$ with Tertiary Thioamides. Romanian Archives of Microbiology and Immunology, 58, 209-215.

[12] Zalaru, F., Cercasov, C., Meghea, A., Zalaru, C. and Jalen, C. (1991) Copper(II) Coordination Compounds with Thioamides. Revue Roumaine de Chemie, 36, 1279-1285.

[13] Dunstan, P.O. and Dos Santos, L.C.R. (1989) Thermochemistry of Amide and Thioamide Complexes of Arsenic Trihalides. Thermochimica Acta, 156, 163-177. http://dx.doi.org/10.1016/0040-6031(89)87182-5

[14] Desseyn, H.O. (1989) Complexes of Chelates of Amides and Thioamides. Pure and Applied Chemistry, 61, $867-872$. http://dx.doi.org/10.1351/pac198961050867

[15] Neagoe, S., Antonescu, L., Negoiu, M., Negoe, V., Negoiuand, D. and Cercasov, C. (1989) Transiton Metal Complexes with Thioamides. Revue Roumaine de Chimie, 34, 845-854.

[16] Carraher Jr., C.E., Chen, W. and Hess, G.G. (1988) Initial Synthesis of Palladium(II) Polyamides and Polythioamides. Polymeric Materials: Science and Engineering, 58, 557-560.

[17] Singh, B. (1987) Studies on Oxovanadium(IV) Complexes of Some Thioamides. Indian Journal of Chemistry Section A, 26, 350-351.

[18] Burns, G.R., DeRoo, C.R., Hall, D.W. and Oliver, A.R. (1987) Chromiun(III) Complexes with Thioamides. Inorganica Chimica Acta, 130, 13-15. http://dx.doi.org/10.1016/S0020-1693(00)85921-6

[19] Bret, J.M., Castan, P. and Laurent, J.P. (1983) Studies on Thioamido-Platinum Complexes: Stabilization of Platinum in Its Higher Oxidation State. Transition Metal Chemistry, 8, 218-221. http://dx.doi.org/10.1007/BF00620694

[20] Muresan, V. and Muresan, N. (1980) Thio Complex Compound Chemistry. Part VIII. Study on the Effect of Ligands and Central Metal Ion on the Nature of Chemical Bond and Structure of Thioamide Complexes. Analete Universitatudin Craiova, 8, 97-101.

[21] Kukushkin, Y.N., Vorob’ev-Desyatovsku, N.V., Sibirskaya, V.V. and Stmkov, V.V. (1980) Some Features of the Behaviour of Platinum(I) Thioamide Complexes in Solutions. Zhurnal Obshchei Khimii, 50, 107-110.

[22] Aarts, A.J., Desseyn, H.O. and Herman, M.A. (1978) Palladium(II) Complexes with Primary Thioamides. Transition Metal Chemistry, 3, 144-146. http://dx.doi.org/10.1007/BF01393531

[23] Sibirskaya, V.V. and Kukushkin, Y.N. (1978) Thioamide Complexes of Platinum Metals. Koordinatsionnaya Khimiya, 4, 963-991.

[24] Molina, M., Del'acqua, A., Melios, C.V., Azevedo, F.A. and Trabuco, E. (1977) Interaction of the Thioamides with Metals. Complexes in the Solid State and in Solution. Eclética Química, 2, 87-95.

[25] Du Preez, J.G.H. and Gibson, M.L. (1970) Phosphine and Thioamide Complexes of Oxovanadium Dichloride. Journal of the South African Chemical Institute, 23, 184-190.

[26] Niederland, J.B. and Sozzi, J.A. (1958) Microanáslisis Elemental Orgánico. Methopress, Buenos Aires.

[27] Kolthoffand, I.M. and Sandall, E.B. (1956) Tratado de Química Analítica, Cuantitativa. 3rd Edición, Nigar, Buenos Aires.

[28] Flaschka, H.A. (1964) Edta Titrations: An Introduction to Theory and Practice. 2nd Edition, Pergamon Press, London.

[29] Dunstan, P.O. (1999) Thermochemistry of Adducts of Bis(2,4-Pentanedionato)Zinc with Heterocyclic Amines. Journal of Chemical \& Engineering Data, 44, 243-247. http://dx.doi.org/10.1021/je980113m

[30] Herington, E.F. (1991) Recommended Reference Materials for the Realization of Physicochemical Properties (Recommendation Approved 1974). Pure and Applied Chemistry, 24, 261-289.

[31] Schofer Sr, M. and Curran, C.B. (1966) Infrared Spectra of Complexes of Metal Halides with Tetramethylurea and Tetramethylthiourea. Inorganic Chemistry, 5, 265-268. http://dx.doi.org/10.1021/ic50036a023

[32] Reedijk, J., Van Leeuwem, P.W.N.M. and Groenveld, W.L. (1968) A Semi-Empirical Energy-Level Diagram for Octahedral Nickel Complexes. Recueil des Travaux Chimiques des Pays-Bas, 87, 129-141. http://dx.doi.org/10.1002/recl.19680870203

[33] Lever, A.B.P. (1968) Electronic Spectra of Some Transition Metal Complexes. Journal of Chemical Education, 45, 711-712. http://dx.doi.org/10.1021/ed045p711 
[34] Bolster, M.W.G. (1972) The Coordination Chemistry of Amino-Phosphinoxide and Related Compounds. Thesis, Leiden University, Leiden.

[35] Dunstan, P.O. (2009) Thermochemistry of Morpholine Adducts of Some Bivalent Transition Metal Bromides. Journal of Chemical \& Engineering Data, 54, 842-846. http://dx.doi.org/10.1021/je8006315

[36] Sovast'yanova, T.N. and Suvorov, A.V. (1999) The Structure and Thermal Stability of Group III Halide Complexes with Pyridine. Russian Journal of Coordination Chemistry, 25, 679-688.

[37] Dunstan, P.O. (2004) Thermochemistry of Adducts of Some Transition Metals(II) Bromides with Pyridine N-Oxide. Thermochimica Acta, 409, 19-24. http://dx.doi.org/10.1016/S0040-6031(03)00333-2

[38] Wagman, D.D., Evans, W.H., Parker, V.B., Schumm, R.H., Hallow, I.S., Churney, M. and Nuttall, R.L. (1982) The NBS Table of Chemical Thermodynamic Properties. Selected Values for Inorganic and $\mathrm{C}_{1}$ and $\mathrm{C}_{2}$ Organic Substances in SI Units. Journal of Physical and Chemical Reference Data, 2, 50-191.

[39] Kubaschewiski, O., Evans, E.L. and Alcock, C.B. (1967) Metallurgical Thermochemistry. 4th Edition, Pergamon Press, London.

[40] Inagari, S.C., Murata, S. and Sakiyama, M. (1982) Thermochemical Studies on Thioacetamide and Tetramethylthiourea. Estimation of Stabilization Energies Due to Interaction between Thiocarbonyl Group and Neighboring Nitrogen Atom. Bulletin of the Chemical Society of Japan, 55, 2808-2813. http://dx.doi.org/10.1246/bcsj.55.2808

[41] Skinner, H.A. and Pilcher, G. (1963) Bond Energy-Term Values in Hydrocarbons and Related Compounds. Quarterly Reviews, Chemical Society, 17, 264-288. http://dx.doi.org/10.1039/qr9631700264 
Scientific Research Publishing (SCIRP) is one of the largest Open Access journal publishers. It is currently publishing more than 200 open access, online, peer-reviewed journals covering a wide range of academic disciplines. SCIRP serves the worldwide academic communities and contributes to the progress and application of science with its publication.

Other selected journals from SCIRP are listed as below. Submit your manuscript to us via either submit@scirp.org or Online Submission Portal.
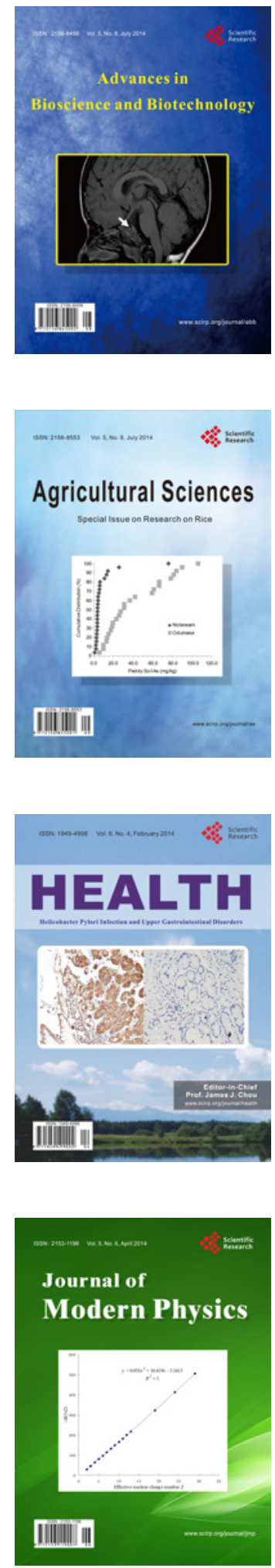
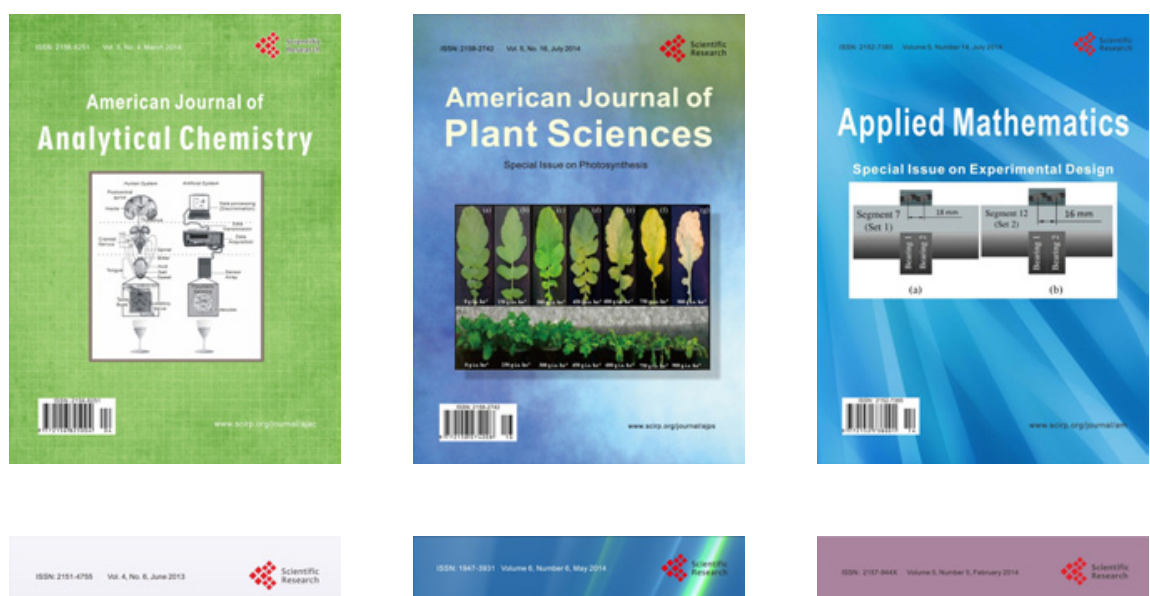

Creative Education
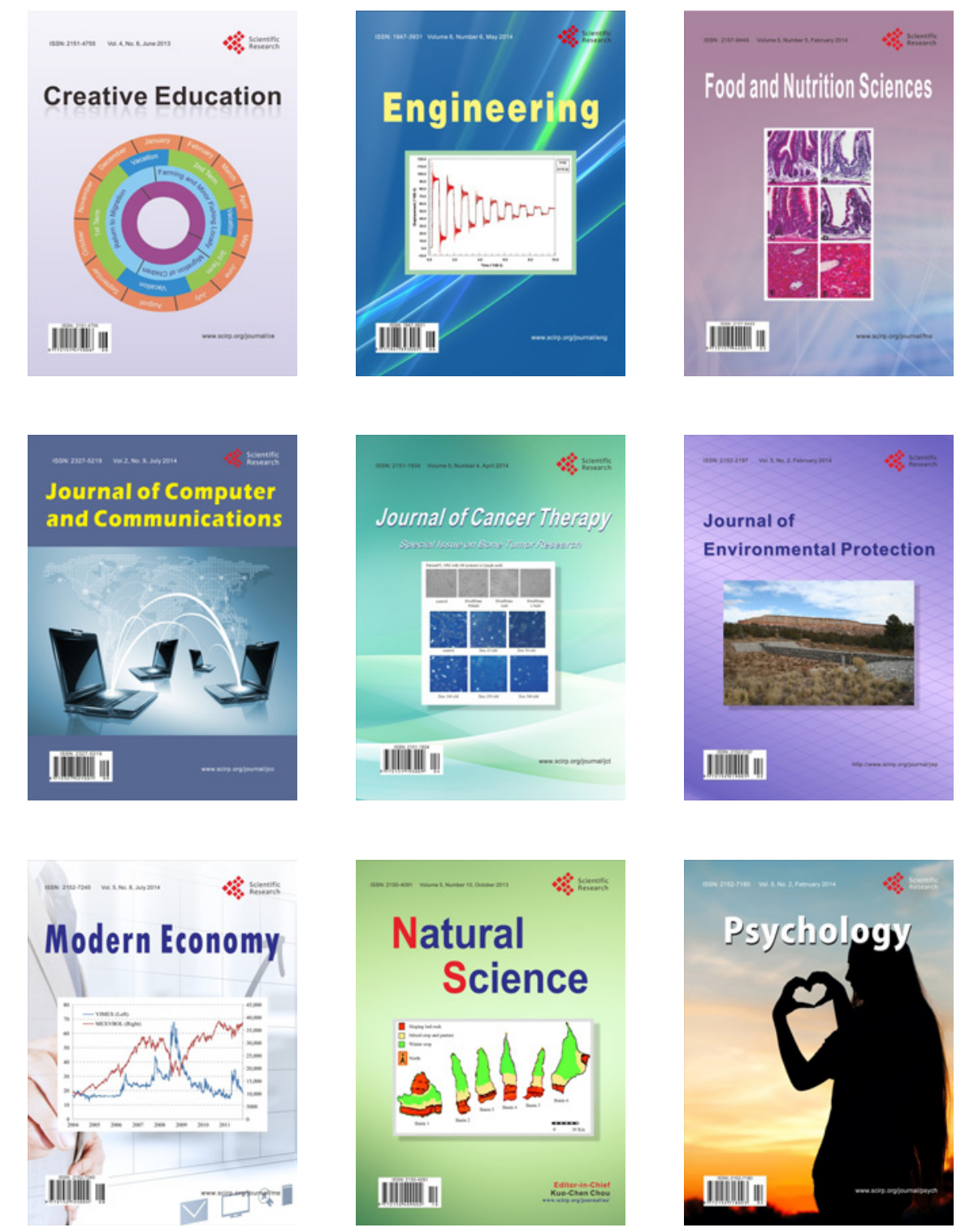